\title{
Population estimate and identification of major conservation threats for the river dolphin (Inia geoffrensis humboldtiana) at the Colombian Orinoquia
}

\author{
Federico Mosquera-Guerra ${ }^{1,2 *}$, Fernando Trujlllo ${ }^{1}$, Carlos Aya-Cuero ${ }^{1}$, Nicole Franco-León ${ }^{1}$, Kelly Valencia ${ }^{1}$, Adrián Vasquez ${ }^{1}$, Camila Duran \\ Prieto ${ }^{1}$, Daniel José Morales-Mejia ${ }^{1}$, Gerhard Alejandro Pachón-Bejarano ${ }^{3}$, Hugo Mantilla-Meluk ${ }^{4}$, and Dolors Armenteras-Pascual ${ }^{1}$ \\ ${ }^{1}$ Fundación Omacha, Calle 84 No. 21-64 Barrio El Polo, 111211, Bogotá. Distrito Central, Colombia. Email:felinos@omacha.org (FM-G), \\ fernando@omacha.org (FT), ekatenkes@hotmail.com (CA-C), sig@omacha.org (NF-L), yasira99@hotmail.com (KV), ragdeadrian@ \\ gmail.com (AV), herpetos@omacha.org (CD-P), danielmorales77@gmail.com (DJM-M), darmenterasp@unal.edu.co (DA-P). \\ ${ }^{2}$ Grupo de Ecología del Paisaje y Modelación de Ecosistemas-ECOLMOD, Departamento de Biología, Facultad de Ciencias, Universidad \\ Nacional de Colombia. Cra 30 No. 45-03, 111321, Bogotá. Distrito Capital, Colombia. Email: fmosquera@unal.edu.co (FM-G). \\ ${ }^{3}$ Corporinoquia, Carrera 23 No. 18-31, Yopal. Casanare, 816010, Colombia. Email: alejandropachon@corporinoquia.gov.co (GAPB). \\ ${ }^{4}$ Universidad del Quindío, Programa de Biología, Carrera 15 No. 12 Norte, 630001, Quindío. Armenia, Colombia. Email: hugo. \\ mantillameluk@gmail.com (HM-M). \\ *Corresponding author
}

South American sub-continent, housed the largest diversity of river dolphins on the planet, here there are two species in the genus Sotalia and three species in the genus Inia. Tonina, present on the Orinoco basin, are exposed to many different anthropogenic threats, such as: the fragmentation and loss of aquatic ecosystems; acoustic contamination; risk of collision with boats; entanglement; deaths by retaliation, resulting from biological and operational interactions with artisanal and industrial fisheries; biomagnification of heavy metals such as mercury in the aquatic trophic web; capture of individuals for their usage as bait for the fishery of Calophysus macropterus, primarily on borderline localities between Colombia and Venezuela; and finally, the negative effects of climate change. We conducted a study to determine population sizes and anthropogenic threats affecting river dolphins populations during the beginning of high-water season, between November 2018 and February of 2019, along $1,402 \mathrm{~km}$. We calculated the degradation index for streams of continental waters and density of the river dolphins. Water quality, habitat transformation, species exploitation, and the increment in number of human settlements were identified as the main conservation stressor in the analyzed area. We obtained density values by habitat type for different aquatic environments and population sizes for river dolphins and the value in the index of degradation, with a potential increment in value through time. River confluences were identified as priority areas for the conservation of the species. Water quality, habitat modification, and species exploitation were particularly intense. Our results highlight a potential transformation of the ideal conditions that allow for the establishment of the species, explaining its distribution with predicted values between $46.6 \%$ and $70.1 \%$ for the evaluated timeframe due to the effects of climate change on aquatic ecosystems. The Meta River, has the highest value for the index of freshwater ecosystems degradation followed by the Orinoco basin, water quality and species exploitation appear to be the major stressors for dolphins in these areas. Finally, river confluences were identified as conservation hot spots for dolphin populations. We point out on the importance of river dolphins as bioindicator, sentinel species, and one of the most susceptible to the negative effects of climate change.

El subcontinente Suramericano, contiene la mayor diversidad de delfines de río del planeta, registrándose dos especies para el género Sotalia y tres especies para el género Inia. La Tonina, presente en la cuenca del Orinoco, está expuesta a diferentes amenazas de origen antrópico, como: la fragmentación y pérdida de los ecosistemas acuáticos; contaminación acústica; riesgo de colisión con embarcaciones; enmallamientos; muerte por retaliación, producto de interacciones biológicas y operacionales con pesquerías artesanales e industriales; biomagnificación de metales pesados como el mercurio en la red trófica acuática; captura de individuos para su uso como atrayente en la pesquería de Calophysus macropterus; y finalmente, los efectos negativos del cambio climático. Esta investigación determinó los tamaños poblaciones y las amenazas de origen antrópico que están afectando las poblaciones de delfines de río durante el período de aguas en ascenso, entre los meses de noviembre 2018 y febrero de 2019, a largo de 1,402 km. Se calculó el índice de degradación de ecosistemas acuáticos continentales y la densidad de los delfines de río. La calidad del agua, la transformación del hábitat, la explotación de especies y el incremento en el número de asentamientos humanos se identificaron como los principales estresor para la conservación de la especie en el área analizada. Se obtuvieron los valores de densidad por ambientes acuáticos y los tamaños de poblacionales para los delfines de río y el valor en el índice de degradación, con un potencial incremento en el valor a través del tiempo. Las confluencias entre ríos fueron identificadas como áreas prioritarias para la conservación de la especie. La calidad del agua, la modificación del hábitat y la explotación de especies fueron particularmente intensas. Los resultados evidencian una transformación potencial de las condiciones ideales que permiten el establecimiento de la especie, explicando su distribución con valores predictivos entre $46.6 \%$ y $70.1 \%$ para el período de tiempo evaluado, influenciado por los efectos del cambio climático en los ecosistemas acuáticos. El Río Meta tiene el valor más alto para el índice de degradación de los ecosistemas acuáticos continentales seguido por la cuenca del Orinoco, la calidad del agua y la explotación de las especies parecen ser los principales estresor para los delfines en estas áreas. Finalmente, las confluencias de los ríos fueron identificados como puntos clave para la conservación para las poblaciones de delfines. Destacamos la importancia de los delfines de río como bioindicadores, especies centinela, y una de las más susceptibles a los efectos negativos del cambio climático.

Keywords: Aquatics mammals; climate change; Orinoco basin; pink dolphins; population density. 


\section{Introduction}

The global decline in species richness and species diversity has been estimated to affect one to ten percent of worldwide biodiversity over a ten-year period (Sittig et al. 2018), but it has also been shown that human interaction accelerates extinction events (Wilcove et al. 1998; Chapin et al. 2000; Dawson 2011; IUCN 2013). To manage the effective conservation of a given animal species, an understanding of its habitat and life history is critical. Although many animal species have been described in detail, standardized population data are still lacking. These studies are necessary to monitor population development and for subsequently determining the level of threat to the species in question, in order to develop and prioritize conservation strategies (Sittig et al. 2018).

River dolphins are among the most threatened cetaceans on the planet (Reeves and Leatherwood 1994; Reeves et al. 2003; Davidson et al. 2009; Ávila et al. 2018); they have been only documented in South America and Asia, in geographic areas that in the last century have experienced some of the most intense transformations due to the impact of human activities (Reeves and Leatherwood 1994; IWC 2000; Reeves et al. 2000, 2003; Smith and Braulik 2008; Trujillo et al. 2010; Mosquera-Guerra et al. 2015). In 2005, it was reported the extinction of the Chinese river dolphin, or baiji, Lipotes vexillifer at the Yangtze River (Turvey et al. 2007; Ross et al. 2010), constituting one of the most recent extinctions of a large mammal (Trujillo et al. 2019). In addition, there are two other species of Asian dolphins under risk of extinction: Platanista gangetica (EN), distributed across the Ganges River complex (India and Nepal), and P. minor (EN), from the Indo (Pakistan) and Megna (Bangladesh) River systems (Smith et al. 2006; Smith and Braulik 2008). The South American sub-continent, housed the largest diversity of river dolphins on the planet with two species in the genus Sotalia and three species in the genus Inia (Mosquera-Guerra et al. 2015, 2018). The genus Sotalia, is represented by $S$. fluviatilis exclusive of continental environments of the Amazon basin (Da Silva 2002), and S. guianensis, documented from the mid-basin and the delta of the Orinoco river, the Maracaibo lake, and the Atlantic Coast in Central and South America from the south of Nicaragua to southern Brazil (Caballero et al. 2007). Molecular data point to a recent divergence of continental populations of $S$. guianensis $(600,000$ years), from their coastal counterparts (Carvajal-Castro et al. 2015; Caballero et al. 2017). Furthermore, vicariate events among basins, associated with the presence of rapids and waterfalls, and the influence of climatic fluctuations, gave origin to three species within the genus Inia: I. geoffrensis (Da Silva 2009), with the subspecies: I. g. geoffrensis, distributed on the Amazon basin (Da Silva 2002), and I. g. humboldtiana, occurring on the Orinoco basin (Herrera et al. 2017). I. boliviensis, from the Mamoré, Itenez, Grande, and upstreams from the Madeira River in Bolivia (Aliaga-Rossel 2002; Banquera-Hinestroza et al. 2002; Aliaga-Rossel et al. 2006; Ruiz-Garcia et al. 2008; Ruiz-Garcia 2010; Gravena et al. 2014). I. araguaiaensis, from the hydrologic complex of the Tocantins-Araguia rivers in Brazil (Hrbek et al. 2014).
Recently the international threatened category of I. geoffrensis was elevated from Data Deficient (DD), to Endangered (EN; da Silva et al. 2018), and in Colombia, this taxon is considered as vulnerable (VU; Trujillo et al. 2006; Minambiente 2017). In addition, the species is within in Appendix II of The Convention on International Trade in Endangered Species of Wild Fauna and Flora (CITES 2019). Populations of I. g. humboldtiana, present on the Orinoco basin (Trujillo 2000; Diazgranados and Trujillo 2004; Mosquera-Guerra et al. 2018a), are exposed to many different anthropogenic threats (Mosquera-Guerra et al. 2016), such as: the fragmentation and loss of aquatic ecosystems; acoustic contamination (Davidson et al. 2012); risk of collision with boats (Ávila et al. 2018). Entanglement; deaths by retaliation, resulting from biological and operational interactions with artisanal and industrial fisheries (Trujillo et al. 2006, 2010; Da Silva 2011; Mintzer et al. 2013). Biomagnification of heavy metals such as mercury in the aquatic trophic web (MosqueraGuerra et al. 2015a, 2018c). Capture of individuals for their usage as bait for the fishery of the mota, simí, piracathinga or come muerto (Calophysus macropterus), primarily on borderline localities between Colombia and Venezuela on the Arauca, Meta, and Orinoco rivers (Mosquera-Guerra et al. 2015c). Finally, river dolphins are affected by the negative effects of climate change on their habitats and populations (Mosquera-Guerra et al. 2015b).

Because of the current scenario, urgent conservation actions are needed to guarantee the persistence of $\mathrm{l} . \mathrm{g}$. humboldtiana on the Colombian Orinoco basin; but their construction and implementation require appropriate data collection on the species habitat use (Gomez-Salazar et al. 2011), as well as, standardized and statistically supported population density estimations (Gomez-Salazar et al. 2012a). This information also provides elements for monitoring I. g. humboldtiana population trends in these rapidly changing landscapes of the Orinoco region (Reeves and Leatherwood 1994; IWC 2000; Reeves et al. 2000; GomezSalazar et al. 2012a). We determined the populations size and conservation threats of toninas in three regions of the Colombian Orinoquia (Meta, Casanare and Vichada), across the Meta, Ele, Cravo Norte, Casanare, Orinoco, Vichada and Inirida rivers, at the beginning of high-water season, between November 2018 and February of 2019, along a total of 1,402 km. Our information on I. g. humboldtiana occurrence, was used to feed predictive species distribution models for the next 20 years at the Colombian Orinoquia.

\section{Material and Methods}

Study area. Between November 2018 and February of 2019, three scientific expeditions were conducted: A) Meta $\left(6.11027^{\circ},-67.28218^{\circ} / 4.21653^{\circ},-72.04838^{\circ}\right)$. B) Ele, Cravo Norte and Casanare Rivers $\left(6.58977^{\circ},-70.7209^{\circ}\right.$ ) $\left.6.04325^{\circ},-69.83514^{\circ}\right)$. C) Orinoco, Vichada and Inirida Rivers $\left(6.18417^{\circ},-67.47140^{\circ} / 3.86514^{\circ},-067.93397^{\circ}\right)$; in order to evaluate the population status and Orinoquian pink dolphins (I. g. humboldtiana); as well as to identify the major threats for the subspecies in the region (Figure 1). 


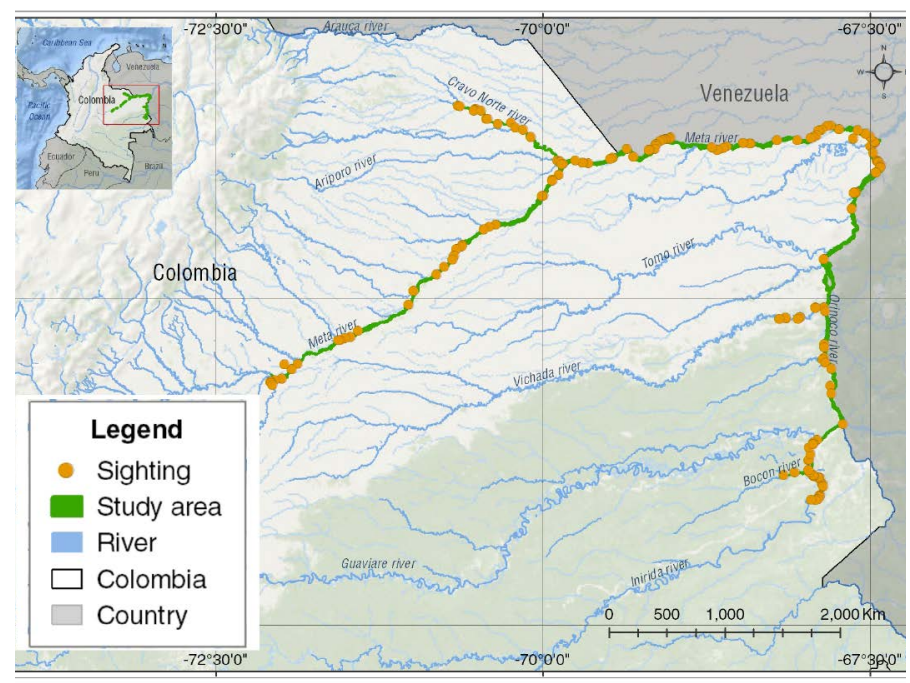

Figure 1. Study area: Meta river transect, from the municipality of Puerto Carreño (Vichada) up to Puerto Gaitán (Meta; 720 km). Ele, Cravo Norte and Casanare transect, from Arauca (Arauca) up to Paz de Ariporo (Casanare; $410 \mathrm{~km}$ ), and Orinoco. Vichada and Inirida rivers transect, from Puerto Carreño (Vichada) up to Puerto Inirida (Guania; 210 $\mathrm{km}$ ), and records of $I . \mathrm{g}$. humboldtiana employed in the construction of different models of distribution for the species in the Colombian Orinoquia.

Transect design. Sampling was conducted with a combination of line and strip-transect methods (Gomez-Salazar et al. 2012a), performing four strip transects of $2.5 \mathrm{~km}$ altogether in length and every a width of 200 meters; then, switching into a line transect between 1.0 and $2.5 \mathrm{~km}$, depending on river width. Boat speed ranged between eight and $12 \mathrm{~km} / \mathrm{hour}$ and data gathering happened between 5:30 and 17:30 hours. The whole sampling occured within the high-water season, allowing for the evaluation of different types of habitats including main rivers, channels, confluences, tributaries, and river islands (Table 1). Boats ranged from 11 to 43 meters of length and were equipped with observation platforms on both bow and stern, varying from two to six meter in height and supporting six previously trained observers on each one. Observers were clockwise rotated in position each two hours. Each platform was considered independent and only one effort recorder knew about the differences in observations between the two platforms, registering them with assigning codes following Gomez-Salazar et al. (2012a).

Inia g. humboldtiana sighting locations were recorded in geographic coordinates with a GPS Garmin $64 \mathrm{sc}$; sight angle was documented with a compass and distance from the dolphin was estimated with a laser range finder distance meter Bushnell Trophy 4X de $20 \mathrm{~mm}$. For each observation the distance to the shore was estimated in ranges as follow: 0 to $50 \mathrm{~m}, 50$ to $100 \mathrm{~m}, 100$ to $150 \mathrm{~m}$ and 150 to $200 \mathrm{~m}$; in the same way riversides were classified into: mainland; forest; bushes; beaches; cliffs; rocks; human settlement; floating grasses. In addition, information on the environmental conditions, including: glare strength; water type (backwaters, white waters, and mix waters, by limnological criteria); river state, was recorded in situ.

Habitat were stratified to generate a differential report on population density with ecological support follow- ing Gomez-Salazar et al. (2012a) and Trujillo et al. (2011): i) main river, ii) tributaries, iii) lake, iv) island, v) channels y vi) confluences. The sampling experimental design followed Gomez-Salazar et al. (2012a; 2012b), Williams et al. (2016), and involved a combination of two types of strip transects (parallel to the shore) and lineal (crossing diagonally the river width).

Human stressors and index of freshwater ecosystems degradation. We determined the degradation index of freshwater ecosystems by transect following Gomez-Salazar et al. (2012b), authors that consider 10 human stressors (Table 2 and 3), grouped into four categories i) water quality; ii) habitat modification; iii) species exploitation; and iv) human settlements and cities (Table 4). Each stressor was valued with a code, according to four categories of impact: 0 ) absence of disturbance; 1 ) low disturbance; 2 ) mid disturbance; and 3) high disturbance. Overall score index of freshwater habitat degradation was obtained by summing over these three major categories with overall value ranges from 0 to 8.5 ( 8.5 being the highest degradation). In addition, the information on human population size (Table 2) for each river area surveyed was obtained using the databases of the population census for each country surveyed (DANE 2018). The future trend in freshwater habitat degradation was estimated for each human stressor based on current knowledge of, for example, water development projects planned (Table 3). Information used to provide current and future degradation index scores consisted of observations in the field, published and unpublished reports, and personal communications with researchers from each location surveyed (see also Gomez-Salazar et al. 2012b).

Population estimation. Population estimate was calculated in DISTANCE version 5.0 y 6.0 (Buckland et al. 2001; Gomez-Salazar et al. 2011a) based on this formula: $D=n$

Table 1. Studied habitats by river: Main rivers, Channels, Confluences, Tributaries, and Islands for the transects: Meta; Ele, Cravo Norte and Casanare; and Orinoco, Vichada and Inirida rivers; Area; Transect length; $N$ trans (number of transects by habitat type); $S$ (stripe transects; and line transects).

\begin{tabular}{|c|c|c|c|c|c|c|c|c|}
\hline \multirow[t]{2}{*}{ Basin } & \multirow[t]{2}{*}{ Rivers } & \multirow[t]{2}{*}{ Habitat type } & \multicolumn{2}{|c|}{ Area $\mathrm{Km}^{2}$} & \multicolumn{2}{|c|}{$\begin{array}{c}\text { Transect } \\
\text { Length Km }\end{array}$} & \multicolumn{2}{|c|}{ No. trans } \\
\hline & & & $\mathbf{S}$ & $\mathbf{L}$ & $\mathbf{S}$ & $\mathbf{L}$ & $\mathbf{S}$ & L \\
\hline \multirow[t]{12}{*}{ Orinoco } & Meta & Channel & 65.7 & - & 131.4 & - & 53.0 & - \\
\hline & & Tributary & 3.7 & - & 7.3 & - & 3.0 & - \\
\hline & & Main river & 257.6 & 4.5 & 515.2 & 9.0 & 209.0 & 6.0 \\
\hline & Ele, Cravo & Channel & 4.9 & - & 9.8 & - & 4.0 & - \\
\hline & $\begin{array}{l}\text { Norte and } \\
\text { Casanare }\end{array}$ & Confluence & 2.5 & - & 5.0 & - & 2.0 & - \\
\hline & & Main river & 100.3 & - & 200.6 & - & 82.0 & - \\
\hline & Orinoco, & Channel & 11.7 & - & 23.4 & - & 10.0 & - \\
\hline & $\begin{array}{l}\text { Vichada and } \\
\text { Inirida }\end{array}$ & Confluence & 1.8 & - & 3.7 & - & 2.0 & - \\
\hline & & Main river & 189.1 & 25.5 & 378.2 & 50.9 & 127.0 & 25.0 \\
\hline & & Island & 6.8 & - & 13.6 & - & 6.0 & - \\
\hline & & Tributary & 27.0 & - & 54.0 & - & 7.0 & - \\
\hline & & $\begin{array}{l}\text { Subtotal } \\
\text { by type of } \\
\text { transect }\end{array}$ & 671.1 & 30.0 & 1.342 & 60.0 & 537.0 & 31.0 \\
\hline Total & & 701.2 & & 1.402 & & 568.0 & & \\
\hline
\end{tabular}


Table 2. Principal human stressors responsible for freshwater degradation and their impact on the ecosystems proposed by Gomez-Salazar et al. (2012b).

\begin{tabular}{|c|c|}
\hline Human stressors & Impact of stressors on freshwater ecosystems \\
\hline Water quantity & $\begin{array}{l}\text { Water withdrawals by domestic, industrial and agricultural } \\
\text { needs, reservoir storage capacity (Alcamo et al. 2003, 2005). }\end{array}$ \\
\hline Water quality & $\begin{array}{l}\text { Source point and non-source point pollutants (e. g., organic } \\
\text { pollutants, increased nutrients, heavy metals, microbial } \\
\text { contamination, toxic organic compounds), suspended particles, } \\
\text { temperature (Hoekstra et al. 2011). }\end{array}$ \\
\hline $\begin{array}{l}\text { Habitat } \\
\text { modification }\end{array}$ & $\begin{array}{l}\text { Roads, dams, reservoirs, land transformation, land use intensity, } \\
\text { agriculture, vegetation cover, fragmentation (Moyle and Randall } \\
\text { 1998; Revenga et al. 2000; Vörösmarty et al. 2010; Alkemade et } \\
\underline{\text { al. 2009). }}\end{array}$ \\
\hline $\begin{array}{l}\text { Exploitation of } \\
\text { species }\end{array}$ & $\begin{array}{l}\text { Fishing pressure, destructive fishing practices (e. g., blast fishing } \\
\text { or fishing using poison or explosives), excessive by-catch and } \\
\text { discards, aquaculture (GIWA 2002). }\end{array}$ \\
\hline Climate change & $\begin{array}{l}\text { Increasing water temperature, decreasing precipitation, } \\
\text { increasing acidification, changes in primary production } \\
\text { (Vörösmarty et al. 2000; Milà-Canals et al. 2009). }\end{array}$ \\
\hline $\begin{array}{l}\text { Introduced } \\
\text { species }\end{array}$ & $\begin{array}{l}\text { Increasing the rates of species introduced in freshwater systems } \\
\text { and the success rate of those introduced (Falkenmark 1997; Karr } \\
\text { and Chu 1999; Bennett et al. 2004). }\end{array}$ \\
\hline
\end{tabular}

$E(\mathrm{i}) f(0) / 2 \mathrm{~L} g(0)$. In which $\mathrm{n}$ is the number of observed groups of dolphins; $E(i)$ is the group mean observed in habitat (i); $f(0)$ is the probability of detection of a density from a perpendicular distance $0 ; L$, refers to the length of the transect; and $g(0)$ is the probability of detection of a group on the line of the transect.

For $g(0)$ we follow the assumptions, as well as the indications in the calculation of the variance in Gomez-Salazar et al. (2011a). For the detection function, we analyze three different models in DISTANCE: uniform, half-normal and hazard rate, that were selected following the Akaike Information Criteria (AIC). Taking into account that we detected a gradient of dolphin density from the shore to the center of the river, the probability of detection $g(0)$ was calculated in a scaled manner using a range of distances $(0$ to $50 \mathrm{~m}, 50$ to $100 \mathrm{~m}, 100$ to $150 \mathrm{~m}$ and 150 to $200 \mathrm{~m}$ ). The population size for river dolphins (Ni) was calculated for each habitat $\mathrm{Ni}=\mathrm{Ai}{ }^{*} \mathrm{Di}$ (Gomez-Salazar et al. 2011a).

Data collection and distribution models for climate change scenarios. In order to construct models of potential distribution for $1 . \mathrm{g}$. humboldtiana in future climate change scenarios for 2018, 2023, 2028, and 2038. Occurrence data represented by 177 georeferenced records obtained from direct observations of dolphins across the Orinoco basin in 2018, were combined with climate datasets from ASCII files for 2020, 2030, 2040 and 2050 with the algorithm Maxent (Graham and Hijmans 2006, Phillips et al. 2006, Peterson et al. 2007). Occurrence data was filtered to avoid redundancy following protocols proposed in Phillips et al. (2009), and was visualized in ArcGIS 10.2.2 (ESRI 2014; Figure 1). Nineteen climatic variables, derived from Worldclim (Hijmans et al. 2005; Table 5), were used in combination with climate shapefiles obtained from the web portal Climate Change, Agriculture and Food Security (CCAFS), selecting the method Delta IPCC AR4 for the region B12. For the intermediate temporalities 2018, 2023, 2028 and 2038 a regression was performed in geostatistical software "R" (R Core Team 2013). We applied the cubic convolution interpolation method in order to downscale bioclimatic variables with a pixel resolution of 100 meters for the analyzed years (ESRI 2019). In addition, we also considered two hydrological variables: i) flux accumulation and ii) flux direction along with a digital elevation model.

In order to select the most informative climate variables for our I. humboldtiana presence data set, we implement the function vifstep from the us $d m$ library in the software R ( R Development Core Team 2011).

\section{Results}

Human stressors and estimation of freshwater ecosystems degradation. The index of freshwater ecosystems degradation, reported low to intermediate values ranging between 2.05 and 4.5, as follows by transect: a) Meta (4.5). b) Ele, Cravo Norte and Casanare (2.05). c) Orinoco, Vichada and Inirida Rivers (4.25; Table 6).

Table 3. Human stressors and definitions for each impact category proposed by Gomez-Salazar et al. (2012b). Codes for impact categories are (0) no disturbance reported, (1) low disturbance, (2) medium disturbance, (3) high disturbance. Some human stressors do not include high impact categories (-).

\begin{tabular}{|c|c|c|c|c|}
\hline \multirow{2}{*}{\multicolumn{2}{|c|}{$\begin{array}{l}\text { Human stressors } \\
\text { I. Water quality }\end{array}$}} & \multicolumn{3}{|c|}{ Impact categories [range distance from the study area] } \\
\hline & & Low (1) & Medium (2) & High (3) \\
\hline 1. Oil exploitation & Any size & $100-200 \mathrm{~km}$ & $50-100 \mathrm{~km}$ & Within $50 \mathrm{~km}$ \\
\hline 2. Tourism & Tourist resorts & $50-100 \mathrm{~km}$ & Within $50 \mathrm{~km}$ & - \\
\hline 3. Ship traffic & $\begin{array}{l}\text { Commercial, } \\
\text { fishing, naval or } \\
\text { transportation. }\end{array}$ & $\begin{array}{l}\text { Sporadic } \\
\text { routes. }\end{array}$ & $\begin{array}{l}\text { Known } \\
\text { shipping } \\
\text { routes. }\end{array}$ & - \\
\hline 4. Mining & Any & $100-200 \mathrm{~km}$ & $50-100 \mathrm{~km}$ & Rango $50 \mathrm{~km}$ \\
\hline \multicolumn{5}{|c|}{ II. Habitat modification } \\
\hline 5. Dams & Any size & $\begin{array}{l}\text { 500-1,000 km } \\
\text { downstream } \\
\text { or 100-200 km } \\
\text { upstream. }\end{array}$ & $\begin{array}{l}200-500 \mathrm{~km} \\
\text { downstream } \\
\text { or 50-100 km } \\
\text { upstream. }\end{array}$ & $\begin{array}{l}\text { Within } 200 \mathrm{~km} \\
\text { downstream and/ } \\
\text { or within } 50 \mathrm{~km} \\
\text { upstream. }\end{array}$ \\
\hline 6. Waterways & Any size & $\begin{array}{l}\text { 500-1,000 km } \\
\text { downstream } \\
\text { or 100-200 km } \\
\text { upstream. }\end{array}$ & $\begin{array}{l}500-1,000 \mathrm{~km} \\
\text { downstream } \\
\text { or 100-200 km } \\
\text { upstream. }\end{array}$ & $\begin{array}{l}\text { Within } 200 \mathrm{~km} \\
\text { downstream and/ } \\
\text { or within } 50 \mathrm{~km} \\
\text { upstream. }\end{array}$ \\
\hline \multicolumn{5}{|c|}{ III. Exploitation of species } \\
\hline $\begin{array}{l}\text { 7. Entanglements/ } \\
\text { killing of } \\
\text { dolphins to avoid } \\
\text { competition for } \\
\text { resources (fish). }\end{array}$ & $\begin{array}{l}\text { Number of dead } \\
\text { dolphins due to } \\
\text { entanglements/ } \\
\text { or direct killing. }\end{array}$ & $\begin{array}{l}\text { Rare (recorded } \\
\text { once or twice } \\
\text { in the area). }\end{array}$ & $\begin{array}{l}\text { Occasional } \\
\text { (recorded once } \\
\text { per year). }\end{array}$ & $\begin{array}{l}\text { Frequent } \\
\text { (recorded at least } \\
\text { once per month). }\end{array}$ \\
\hline $\begin{array}{l}\text { 8. Killing of river } \\
\text { dolphins for bait }\end{array}$ & $\begin{array}{l}\text { Number of dead } \\
\text { dolphins killed } \\
\text { for bait. }\end{array}$ & $\begin{array}{l}\text { Rare (recorded } \\
\text { once or twice } \\
\text { in the area) }\end{array}$ & $\begin{array}{l}\text { Occasional } \\
\text { (recorded once } \\
\text { per year). }\end{array}$ & $\begin{array}{l}\text { Frequent (e.g., } \\
\text { mota fishery } \\
\text { established in the } \\
\text { area). }\end{array}$ \\
\hline 9. Fisheries & & Subsistence. & $\begin{array}{l}\text { Commercial, } \\
\text { main } \\
\text { destination is } \\
\text { cities within } \\
\text { the river basin. }\end{array}$ & $\begin{array}{l}\text { Commercial, main } \\
\text { destination is } \\
\text { cities within and } \\
\text { outside the river } \\
\text { basin. }\end{array}$ \\
\hline \multicolumn{5}{|c|}{ IV. Human settlements and cities } \\
\hline $\begin{array}{l}\text { 10. Human } \\
\text { population size }\end{array}$ & & $\begin{array}{l}\text { Less than } \\
100,000\end{array}$ & $\begin{array}{l}\text { Between } \\
100,000 \text { and } \\
200,000 \text {. }\end{array}$ & $\begin{array}{l}\text { More than } \\
200,000 \text {. }\end{array}$ \\
\hline
\end{tabular}


Table 4. Overall score index for each impact category (high, medium and low, see Table 3) and risk trend levels of freshwater ecosystem degradation. The overall score index is the sum of the means over the four main categories of human stressors (water quality, habitat modification, exploitation of species, cities and human settlements, Table 3 ).

\begin{tabular}{|c|c|c|}
\hline & Overall score index & $\begin{array}{l}\text { Summing over the different } \\
\text { types of human stressors }\end{array}$ \\
\hline High & $\begin{array}{l}\text { Majority of human stressors are } \\
\text { classified as high or medium, no } \\
\text { stressors are classified as low. }\end{array}$ & $\geq 4$ \\
\hline Medium & $\begin{array}{l}\text { Majority of human stressors are } \\
\text { classified as medium. }\end{array}$ & $\geq 3$ and $<4$ \\
\hline Low & $\begin{array}{l}\text { Majority of human stressors are } \\
\text { classified as low or no known, no } \\
\text { stressors are classified as high. }\end{array}$ & $<3$ \\
\hline \multicolumn{3}{|c|}{ Risk trend (within the next 10 years) } \\
\hline$\uparrow$ & \multicolumn{2}{|c|}{$\begin{array}{l}\text { Risk is expected to increase (e. g., construction of water development } \\
\text { projects planned, increase number of oil stations, etc.). }\end{array}$} \\
\hline$\rightarrow$ & \multicolumn{2}{|c|}{$\begin{array}{l}\text { Risk is expected to remain similar, although some increase in human } \\
\text { population size is expected. }\end{array}$} \\
\hline$\downarrow$ & \multirow{2}{*}{\multicolumn{2}{|c|}{$\begin{array}{l}\text { Risk is expected to reduce given some conservation or management } \\
\text { actions in the area. } \\
\text { Risk not recorded in the area, and not expected to appear in the next } \\
\text { year. }\end{array}$}} \\
\hline- & & \\
\hline
\end{tabular}

Population status. For $1.402 .2 \mathrm{~km}$ surveyed, at the beginning of the rainy season, a total of 654 individuals were recorded, discriminated by river as follows: Meta = 206; Ele, Cravo Norte and Casanare = 89; and Orinoco, Vichada and Inirida = 359 (Table 7).

The greatest values of density were registered for the type of habitat "confluences", with the confluence

Table 5. Bioclimatic variables used in the potential distribution models of $I . g$. humboldtiana in the Orinoco basins.

\begin{tabular}{ll}
\hline Variables & Description \\
\hline Elevation & Height in meters above sea level \\
Bio 1 & Annual average temperature \\
Bio 2 & Average daytime range (Mean of the month (Max Temp - Min Temp)) \\
Bio 3 & Isothermality ((Bio 2/Bio 7) ${ }^{*}$ 100) \\
Bio 4 & Seasonality of temperature (Standard deviation * 100) \\
Bio 5 & Maximum temperature of the hottest month \\
Bio 6 & Minimum temperature of the coldest month \\
Bio 7 & Annual temperature range (Bio 5 - Bio 6) \\
Bio 8 & Average temperature of the wettest quarter \\
Bio 9 & Average temperature of the driest quarter \\
Bio 10 & Average temperature of the warmest quarter \\
Bio 11 & Average temperature of the coldest quarter \\
Bio 12 & Annual rainfall \\
Bio 13 & Precipitation of the wettest month \\
Bio 14 & Precipitation of the driest month \\
Bio 15 & Seasonality of precipitation (Coefficient of variation) \\
Bio 16 & Precipitation of the wettest quarter \\
Bio 17 & Solar radiation \\
Bio 18 &
\end{tabular}

Table 6. Score index and risk trends of freshwater ecosystem degradation, and human population size across the three areas surveyed. The direction of the arrows indicates whether the risk of degradation is expected to increase, decrease or remain the same. Overall score index is the sum of the means over the four main categories of human stressors (water quality, habitat modification, exploitation of species, cities and human settlements; Gomez-Salazar et al. 2012b).

\begin{tabular}{|c|c|c|c|}
\hline Human stressors & $\begin{array}{l}\text { Meta } \\
\text { river }\end{array}$ & $\begin{array}{c}\text { Rivers } \\
\text { Ele, Cravo } \\
\text { Norte and } \\
\text { Casanare rivers }\end{array}$ & $\begin{array}{l}\text { Vichada } \\
\text { Orinoco and } \\
\text { Inirida rivers }\end{array}$ \\
\hline Overall score risk & 4.5 & 2.05 & 4.25 \\
\hline I. Water quality & 2.5 & 0.75 & 2.25 \\
\hline 1. Oil & $3 \uparrow$ & $1 \uparrow$ & - \\
\hline 2. Tourism & $2 \uparrow$ & - & $3 \uparrow$ \\
\hline 3. Ship traffic & $2 \uparrow$ & $1 \uparrow$ & $3 \uparrow$ \\
\hline 4. Minning & $3 \uparrow$ & $1 \uparrow$ & $3 \uparrow$ \\
\hline II. Habitat modification & - & - & - \\
\hline 5. Dams & - & - & - \\
\hline 6. Waterways & - & - & - \\
\hline III. Species exploitation & $2 \rightarrow$ & $1.3 \rightarrow$ & $2 \rightarrow$ \\
\hline $\begin{array}{l}\text { 7. Accidental entanglements } \\
\text { / dolphin deaths due to } \\
\text { competition for resources (Fishes) }\end{array}$ & $2 \uparrow$ & $2 \uparrow$ & $2 \uparrow$ \\
\hline 8. Killing of river dolphins for bait & $1 \uparrow$ & - & $1 \uparrow$ \\
\hline 9. Fisheries & $3 \uparrow$ & $2 \uparrow$ & $3 \uparrow$ \\
\hline IV. Cities and human settlements & - & - & - \\
\hline 10. Human Population Size & 181,276 & 3,331 & 34,274 \\
\hline
\end{tabular}

between the Meta-Orinoco yielding a density value $D=$ 17.6 Inia $/ \mathrm{km}^{2}$, following by the confluence of the river system of Ele, Cravo Norte and Casanare, $D=1.2 \mathrm{Inia} / \mathrm{km}^{2}$ (Table 8). Average group size was $2.9(S D=1.5)$ for the Ele, Cravo Norte and Casanare rivers; $2.6(S D=1.9)$ Orinoco, Vichada and Inirida; and $2.0(S D=1.4)$ Meta.

The habitat type "main river" showed values ranging between $D=1.6-0.8 \mathrm{Inia} / \mathrm{km}^{2}$ for Meta, Ele, Cravo Norte and Casanare; while, Vichada River had a value of $D=0.6$ Inia $/ \mathrm{km}^{2}$. Channels had density values ranging from $D=$ 0.3 to $0.5 \mathrm{Inia} / \mathrm{km}^{2}$ only recorded for the Meta and Orinoco-Vichada. Finally, Island density was $D=0.6 \mathrm{Inia} / \mathrm{km}^{2}$ for the Orinoco and Vichada (Figures 2a-b).

Niche modeling and climate change. We modeled the potential distribution of $I$. g. humboldtiana for predicted scenarios of climate change for the following temporal windows: 2018 yield an area of 1,467 km² (AUC: 0.97); 2023, $784.3 \mathrm{~km}^{2}$ (AUC: 0.96), 2028, $575.6 \mathrm{~km}^{2}$ (AUC: 0.96), and finally $2,038440 \mathrm{~km}^{2}$ (AUC: 0.94; Figures 3a-d).

\section{Discussion}

River dolphins are considered ideal biological models to understand the dynamics of the aquatic ecosystems at the basin scale; characteristics such as: i) low population size; ii) high habitat requirements; iii) differential use of their habitats; iv) location as top predators within the trophic web; v) long pregnancy (Martin and Da Silva 2018; Boede et al. 
Table 7. Values of the density of I. g. humboldtiana in the different types of habitat sampled for each of the systems evaluated. $D i$ is the densities for the habitat type, $A i$ is the survey area and $\mathrm{Ni}$ is the population size calculated for the river dolphins.

\begin{tabular}{|c|c|c|c|c|}
\hline River & Habitat type & Area $\left(\mathrm{km}^{2}\right)$ & $D i$ & $N i=A i^{*} D i$ \\
\hline \multirow[t]{3}{*}{ Meta } & Channel & 65.7 & 0.3 & 20 \\
\hline & Tributary & 4.0 & 1.6 & 6 \\
\hline & Main River & 258 & 0.7 & 180 \\
\hline \multirow[t]{3}{*}{ Ele, Cravo Norte and Casanare } & Channel & 4.9 & & 0 \\
\hline & Confluence & 2.5 & 1.2 & 3 \\
\hline & Main River & 100.3 & 0.8 & 86 \\
\hline \multirow[t]{5}{*}{ Orinoco, Vichada and Inirida } & Channel & 11.7 & 0.5 & 6 \\
\hline & Confluence & 1.8 & 17.6 & 33 \\
\hline & Main River & 153 & 1.8 & 276 \\
\hline & Island & 6.8 & 0.6 & 4 \\
\hline & Tributary & 8.8 & 4,6 & 40 \\
\hline
\end{tabular}

2018); and vi) long term parental care (Boede et al. 2018). Make these cetaceans sensitive to the environmental changes, and by means sentinel and bioindicator species of the aquatic environments (Trujillo et al. 2010; Gomez-Salazar et al. 2012; Herrera et al. 2017; Mosquera-Guerra et al. 2018; Trujillo et al. 2019). The constant direct and indirect threats faced by river dolphins and their habitats across the Colombian Orinoquia, had made a priority the construction of conservation actions to guarantee their existence, as into account for the appropriate design of conservation strategies is the generation of well as the multiple structural functions these cetaceans offer to their environments. One of the most important aspects to take information on population size and its relationship with the health of the environment across species distribution (Trujillo et al. 2011; Mosquera-Guerra et al. 2018). After almost a decade of continues research, we have population estimates for $\mathrm{l} . \mathrm{g}$. humboldtiana across the Orinoco basin in the Arauca, Meta, Bita, Orinoco, Guaviare, Guayabero and Losada Rivers (Mosquera-Guerra et al. 2015, 2018; Trujillo et al. 2019).

Human stressors and estimation of freshwater ecosystems degradation. These values are in agreement with data reported in Gomez-Salazar et al. (2011) and MosqueraGuerra et al. $(2015,2016)$ the mid Orinoco River. It is important to mention that human stressors have a differential intensity along the hydrologic systems evaluated, varying in parameters such as: water quality; the type of habitat

Table 8. Average of the sighting rate $(n / I)$, density estimate $(D)$ and coefficient of variation to measure the rate of encounter CV (er) for the aquatic systems evaluated during the hydrological period of low water.

\begin{tabular}{|c|c|c|c|c|c|c|c|c|c|}
\hline \multirow[t]{2}{*}{ Habitat } & \multicolumn{3}{|c|}{ Meta River } & \multicolumn{3}{|c|}{$\begin{array}{c}\text { Ele, Cravo Norte and } \\
\text { Casanare Rivers }\end{array}$} & \multicolumn{3}{|c|}{$\begin{array}{l}\text { Orinoco, Vichada and } \\
\text { Inirida Rivers }\end{array}$} \\
\hline & N/L & $\begin{array}{c}\mathrm{D} \\
\text { Inial } \\
\mathrm{km}^{2}\end{array}$ & Cv(er) & $N / L$ & $\begin{array}{c}\text { D } \\
\text { Inial } \\
\mathbf{k m}^{2}\end{array}$ & Cv(er) & $N / L$ & $\begin{array}{c}\mathrm{D} \\
\text { Inial } \\
\mathbf{k m}^{2}\end{array}$ & $\mathrm{Cv}(\mathrm{er})$ \\
\hline Channel & 0.06 & 0.30 & 0.16 & & & & 0.10 & 0.50 & 0.10 \\
\hline Confluence & & & & 0.20 & 1.20 & 0.10 & 3.10 & 17.60 & 0.08 \\
\hline Tributary & 0.30 & 1.60 & 0.30 & 0 & 0 & 0 & 0.10 & 4.60 & 0.04 \\
\hline Main River & 0.10 & 0.70 & 0.30 & 0.20 & 0.80 & 0.10 & 0.10 & 1.80 & 0.01 \\
\hline Island & & & & & & & 0.10 & 0.60 & 0.03 \\
\hline
\end{tabular}

a)

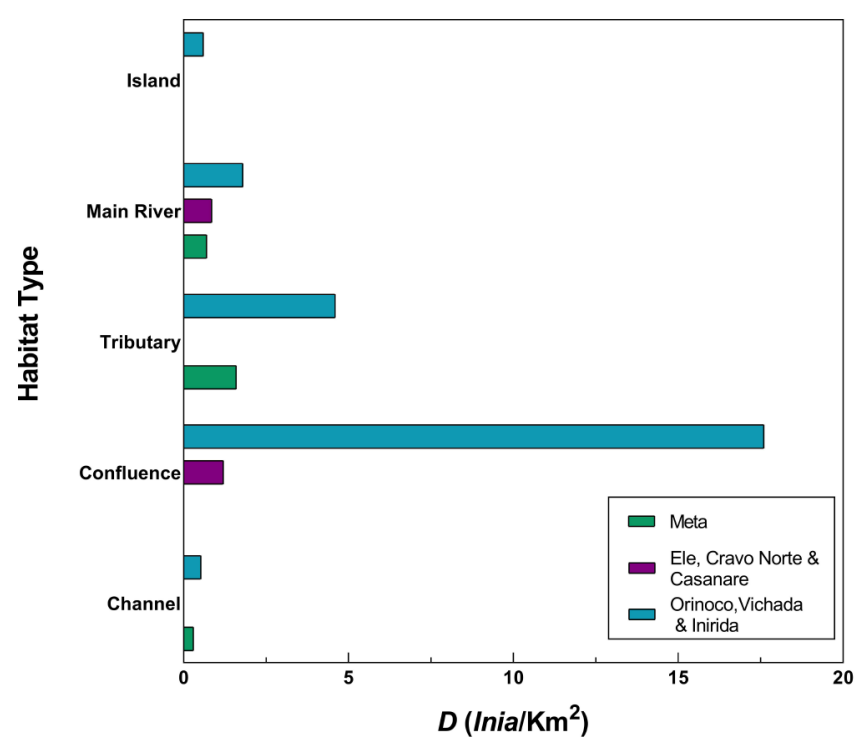

b)

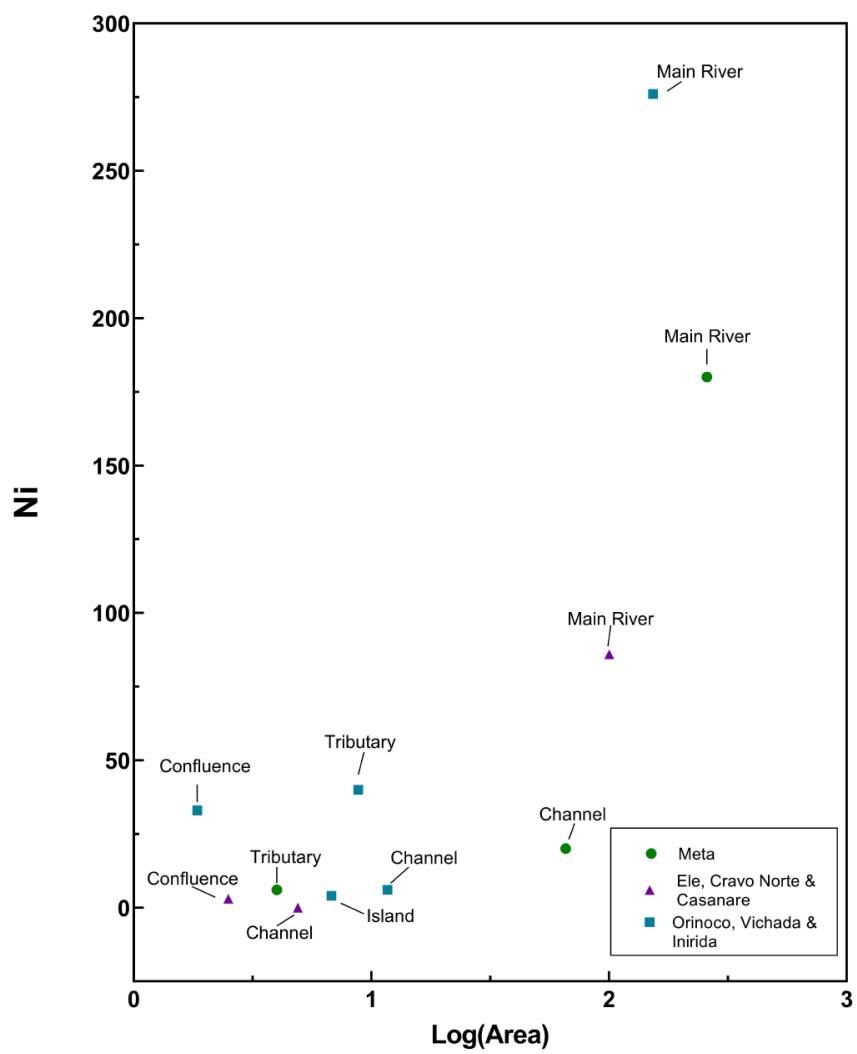

Figures 2. Values of density and population size of I. g. humboldtiana, in the different types of habitat sampled for each of the systems evaluated. a) values of density in $\mathrm{km}^{2}$ and b) population size calculated for the river dolphins in Log (area).

modifications; fisheries exploitation; and boat traffic volume, among others.

Other aspect that contributes to the affectations complexity, is derived from the natural heterogeneity of the savannas of the Colombian Llanos Orientales, enclosing at least 156 different types of ecosystems, 49 correspond to areas with some degree of human transformation (Romero et al. 2004). The agroindustrial plantations establishment of African palms (E. guineensis), maize (Z. mays), and rice $(O$. sativa), and during the last twenty years, the increment in 
acacias (Acacia sensu) and eucaliptus (Eucalyptus sp.) plantations. In conjunction, monocultures are some of the transformation gears at the landscape scale in the Orinoquia (Andrade et al. 2009). Agro-industrial activities demand large volumes of water, situation that in combination with the natural hydrological stress, derived from the region seasonality, affecting, in particular, the tributaries contribution, compromising the ecological dynamics as a consequence of his dependence of structural changes in area and volume, importance variables for large aquatic vertebrates such dolphins. The situation aforementioned is particularly true for the Casanare, Cravo Sur, and Meta Rivers, tributaries of the Meta basin (Mosquera-Guerra et al. 2015). The increment in human settlements and cities, consequence of massive migration is an outgrowth of agroindustrial megaprojects in the Colombian Orinoquia (Mosquera-Guerra et al. 2016). Major human centers in the region are characterized by a poor infrastructure and coverage for water treatment. Sewage dumping in municipalities such as Puerto Carreño (Vichada), Cravo (Arauca) and Orocue (Casanare), as well

a)

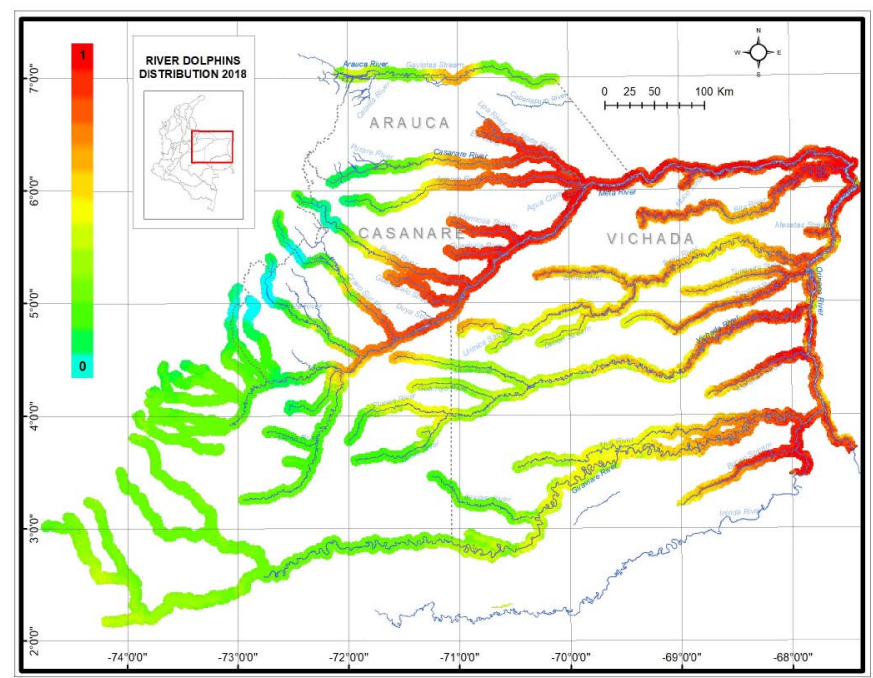

c)

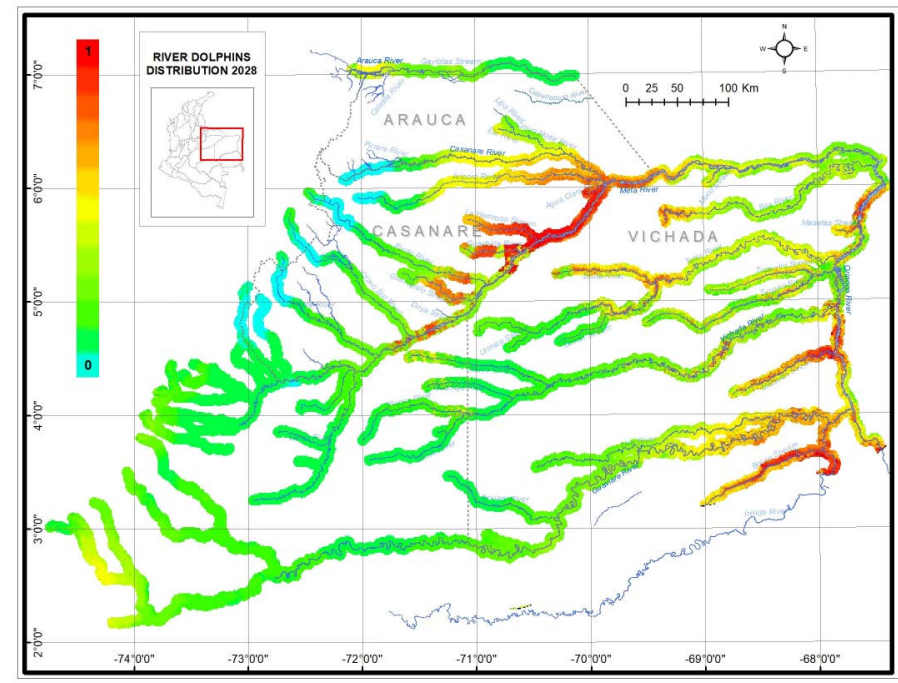

as the disposal of solid residuals along the Meta, Ele, Cravo Norte, Casanare, Vichada, Orinoco, and Inirida rivers.

Deforestation and fires intentionally promote by human activities, along the river shores, compromised their structural stability, increasing the amount of sediments discharged into the river systems, and the total dissolved soils, affecting biogeochemical cycles, the turbidity, conductivity, acidity and amount of heavy metals. All these effects result in changes in the ecological dynamics of water systems (Mosquera-Guerra et al. 2015a, 2018c). Previous estimation showed that the region suffers an annual transformation of $1.3 \%$ of its forest coverage.

In contradiction with these statistics, and despite the warnings they have raised among scientists, at the Consejo Nacional de Política Económica y Social (2014) implemented a new economic policy for the Altillanura (nonflooded savannah), in which the "Departamento de Planeación Nacional" (DNP) suggest that around 2.8 millions of hectares in the region are free to be transformed into productive systems (Mosquera-Guerra et al. 2015).

b)

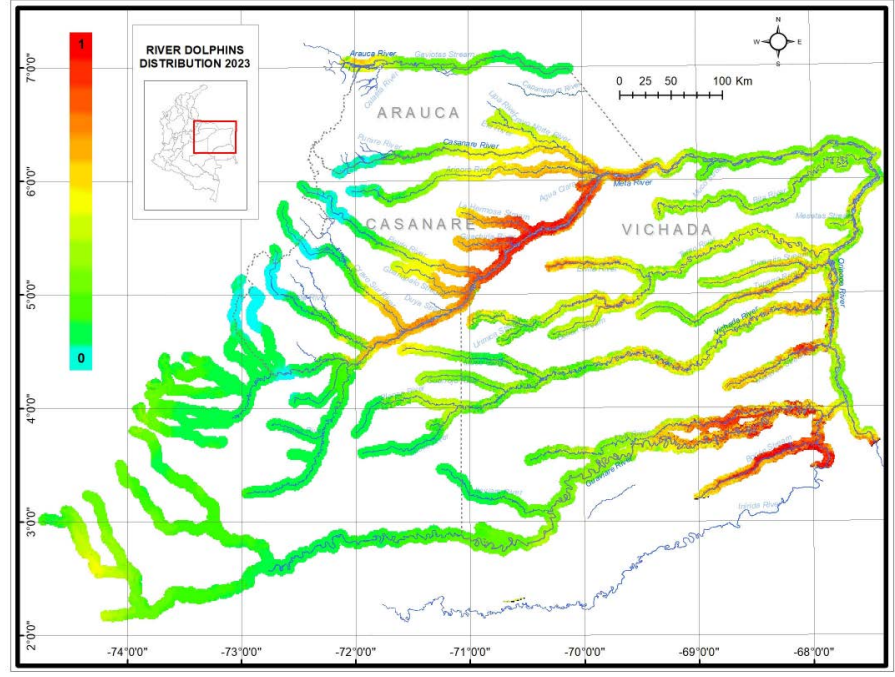

d)

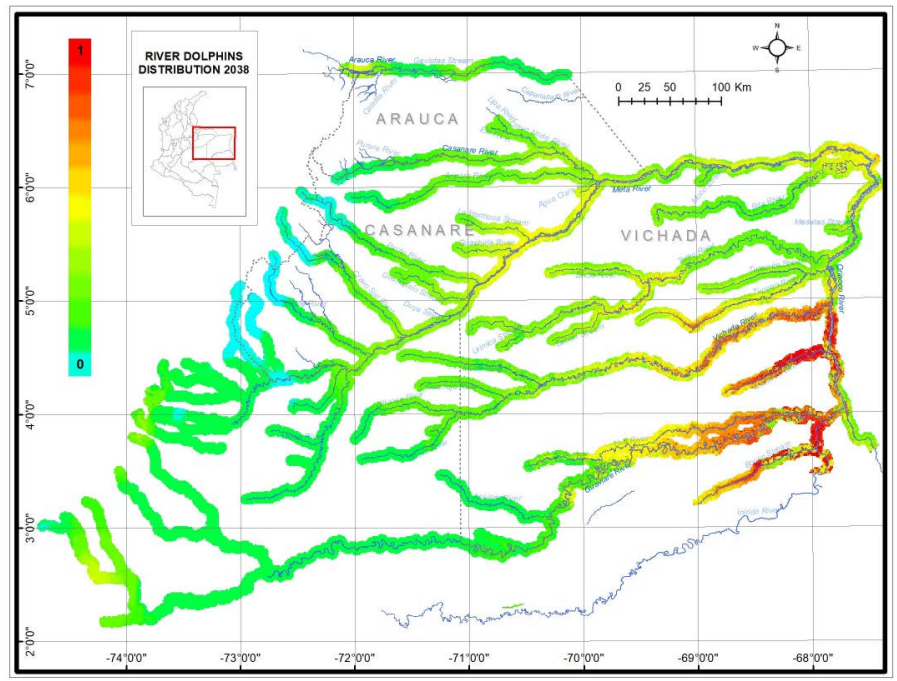

Figures 3. Models of potential distribution for l.g. humboldtiana in the Orinoco basin for a) 2018, b) 2023, c) 2028 , and d) 2038. 
We also evidence an expansion of oiling activities across the study area, in particular for the high and middle basin of the Meta River (Gomez-Salazar et al.2011; Mosquera-Guerra et al. 2016). Since the 1980's oil spills, due to subversive activities of the guerrillas, resulted in 1.5 million of barrels, contaminating primarily the aquatic systems of the Arauca and Casanare basins (Trujillo et al. 2010). Product of these perturbations, large amounts of heavy metals are released into the hydrological system, starting a process of biomagnification, with large vertebrate carnivores (river dolphins, giant otters, and cat fishes, among other animals) as final repositories of these metals in their tissues. MosqueraGuerra et al. (2015a, 2018c), report the maximum amount of mercury $(\mathrm{Hg})$ among South American river dolphins, in muscle tissue samples of I. g. humboldtiana from the Arauca $\operatorname{River}\left(3.5 \mathrm{mg} / \mathrm{kg}^{-1}\right)$.

We also identify that the inadequate closure of oil drills, are a potential threat of oil spills. The new economic policies that authorize the implementation of extractive techniques like the fracking emerge as new potential threat for the aquatic environments (Mosquera-Guerra et al. 2016). On the other hand, touristic activities, are generating an increment in the traffic of boats, raising the number of evidence of collisions (scars in the fins and even dead animals have been documented) in particular for the Orinoco and Vichada Rivers, also the considerable increment of acoustic contamination, associated with commercial activities, and human transportation, taking into consideration that these two rivers in a region that lacks of other ways to access affect the dolphin reproductive sites, such as the confluences of Meta-Orinoco and Vichada-Orinoco Rivers. The structural modification of the river courses to in order favor a greater volume of boat traffic (hydro-highways), will also carry many of the serious problems mentioned above. One of the major causes for the extinction of the Chinese baijii (Lipotes vexillifer) was the fragmentation of their population (Trujillo et al. 2010).

Population status. These results agree with information reported in Gomez-Salazar et al. (2011, 2012a, 2012b), Mosquera-Guerra et al. $(2015,2018)$ and Pavanato et al. (2016). The reported values of group size in the present work are within the averages documented by Gomez-Salazar et al. (2011) and Mosquera-Guerra et al. (2015), for Orinoco basin. Variation in density is strongly influenced by habitat type. The ecological heretogeity of aquatic habitats across the Orinoco basin, determines a differential spatial-temporal use of the river by these cetaceans. Species in Inia can differentially use, main rivers, their tributaries, and flooded forest environments at different spatial and temporal scales. Confluences, tributaries, lakes and flooded forest are commonly used for feeding; shallow waters are the environments where individuals of the species mate and socially interact; and lakes and channels are used for the birth and care of offspring (Trujillo 2000; Martin and da Silva 2004, 2006; Gomez et al. 2012, Mosquera-Guerra et al. 2018b). Inia is intrinsically dependent on the dynamics of flood pulses of the basins and their effect on the temporal and spatial distribution of their fish prey (Mosquera-Guerra et al. 2018b). Other studies have reported variations in density values for river dolphin density and group size associated with ecological factors such as flood pulses, highlighting that at low waters, river dolphins are concentrated on the channels, river confluences and tributaries. But, at high waters, individuals spread into other aquatic systems, associated with the flooded forest, in the foraging for fish preys (Trujillo et al. 2011, Gomez-Salazar et al. 2012a and Mosquera-Guerra et al. 2015a).

The present study corroborates, the ecological importance of river confluences for pink dolphins, in particular, Meta-Orinoco and Orinoco-Vichada; evidencing, its relevance as prioritized conservation areas for the subspecies (Figure 4a). River confluences are ecotones in which contrasting ecological conditions determine the selection of a differential fish communities. In the Orinoco basin, white water rivers such as the Meta, Arauca, and Casanare, encounter clear water rivers such as the Bita, Tomo, Tuparro and Vichada and are obligated passes for fish populations moving up and down-streams. The last generates: i) ideal conditions for dolphin fishing success and ii) it conditions the generation of social groups among dolphins.

The highest values among analyzed habitats, reported by confluences, agrees with Trujillo (2000), Trujillo and Diazgranados (2004), Gomez-Salazar et al. (2011), Trujillo et al. (2016) and Mosquera-Guerra et al. (2018b). These authors, also associated the greatest number of individuals with the confluence of the Meta-Orinoco Rivers. In part, the greatest density of dolphins reported for the confluences, is closely related with the presence of fish in these areas that offer connection among different aquatic environments. In summary the stressors of human origin that influence the population dynamic of river dolphins are: habitat degradation, loss of connectivity, contamination, conflict with fisheries, increment of the traffic, climate change, and construction of hydroelectric infrastructure (Sandin et al. 2008; Baum and Worm 2009; Gomez-Salazar et al. 2012b; Mosquera-Guerra et al. 2015a; Trujillo et al. 2010a). Population estimates for river dolphins in Colombia and South America, have produced concrete results during the last 12 years, resulting in the change in the category of threat for l. geoffrensis by the IUCN, from Data Deficient (DD) to Endangered species (EN) in 2018 along with the formulation and implementation of regional and national management plans.

We infer a strong annual population reduction of $I$. g. humboldtiana at the Orinoco basin $(7.14 \%)$. This inference is derived from the comparison of our population data ( 2017 to 2018; 654 individuals) with that in Gomez-Salazar et al. (2012), representing a decrease of $35.7 \%$ in the number of individuals in six years. Our data is in agreement with Williams et al. (2016) for the Colombian Amazon; who reported a reduction of $10 \%$ per year for the populations of $I . g$. geoffrensis between 1993 and 2007. This condition in both basins (Amazon and Orinoco) can be explained by the increasing in 
direct captures of dolphins to be used as bait for the fishery of the mota, simí, piracathinga or come muerto (Calophysus macropterus); augment in entanglements; and recently, strandings due to rapid changes in river flow.

Niche modeling and climate change. The Orinoquia is one of the most vulnerable ecoregions to climate change in Colombia. As suggested by the tools of climate action of the Ministry of Environment and Sustainable Development (MADS) of Colombia, and the Integral Regional Plan of Climate Change for the Orinoquia, it is thought that by 2100 , temperature in the region will experience an increment between $2.61^{\circ} \mathrm{C}$ and $2.7^{\circ} \mathrm{C}$ above the average reference value (1976 to 2005), and precipitations will decrease in average a $10 \%$ for the whole Orinoquian savannahs (CIAT et al. 2018). The region encloses strategic aquatic ecosystems highly vulnerable and with low resilience such as the humedales de sabana ecosystems that contribute with the hydrologic balance of many basins of Andean origin including the: Arauca, Casanare, y and Meta basins, as well as Orinoquian origin such as the: Bita, Tomo, Tuparro and Vichada basins, part of the Orinoco macrobasin. Within this context, it is necessary to identify those negative effects of climate change on the aquatic ecosystems associated with the ecoregion. River dolphins are natural bio-indicators, widely distributed across the basin, allowing for an exploration of the changes in the climate niche of a large aquatic mammals, responsible of the structure of the vertebrate community in this type of systems. Our results highlight a potential transformation of the ideal conditions that allow for the establishment of the species, explaining its distribution with predicted values between $46.6 \%$ and $70.1 \%$ for the evaluated timeframe. The areas that within our models are going to experience the most drastic changes are associated with the Inirida and Guaviare basins, area of transition between the bioregions of the Amazon and the Guayana.

This results are in agreement with Trujillo et al. (2010, $2011,2016)$ and Mosquera-Guerra et al. $(2015,2018)$, these authors document the increment in habitat transformation important for river dolphin populations, due to the variability of the hydrologic courses across the Orinoco basin, phenomenon mostly associated with climate change. This situation is evidenced by the increment in the number of stranded of river dolphins between 2015 to 2019 in localities such as Caño Agua Limón, tributary the Arauca River, main channel of the Arauca River (Arauca) and Orinoco (Vichada), in the surroundings of Santa Helena island, in where more than 10 stranding events have been reported in recent years (Figure $4 b$ ).

Due to their high seasonality, the Colombian Orinoquia is one of the most vulnerable regions to the negative effects of climate change in the country. The whole region intrinsically depends on water pulses that determine the phenological cycles of plants and animals in particular fish production. Hydrometeorological data in the Orinoquia, have documented strong variations in temperature and hydrologic dynamics, with episodes of both drastic a)
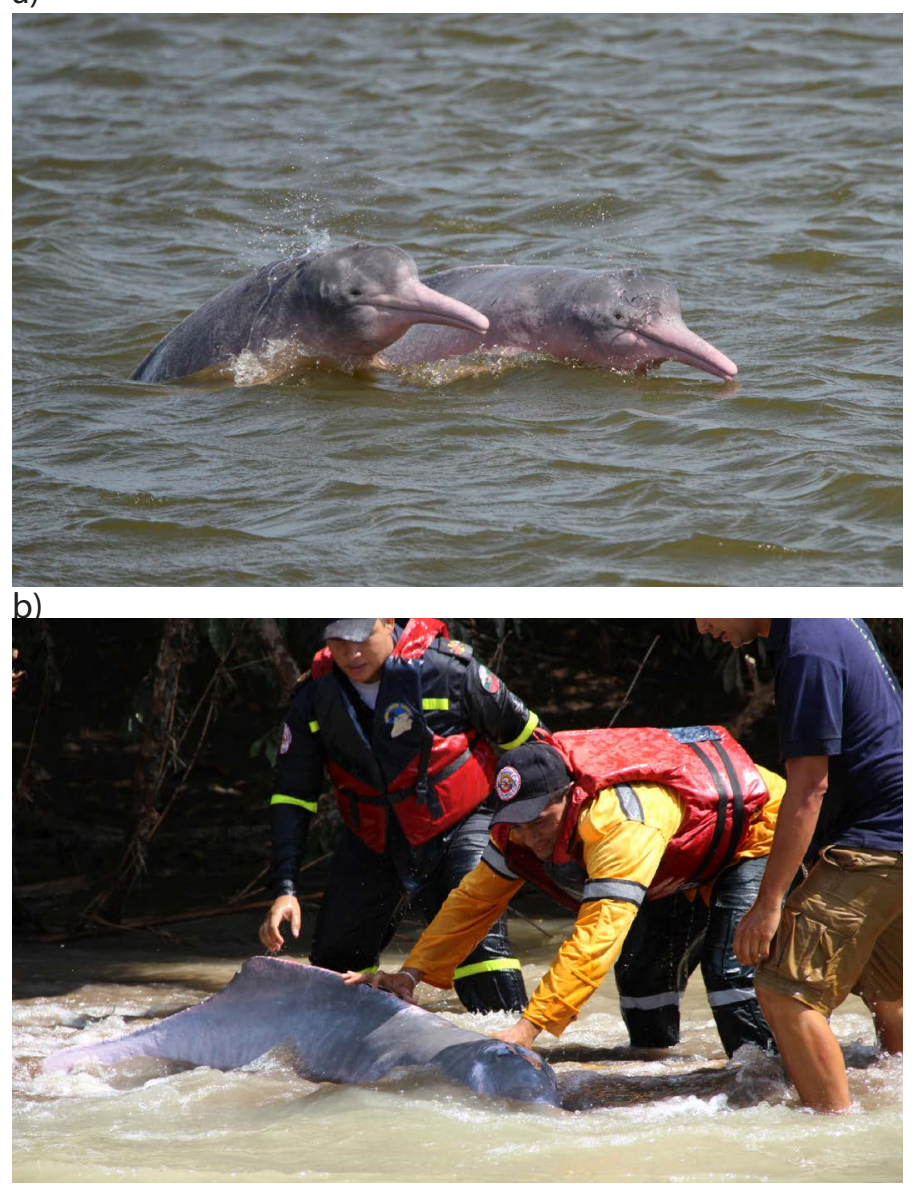

Figures 4. a) Hunting behavior of two individuals of I.g. humboldtiana obtained at the confluences between the Meta-Orinoco and Bita-Orinoco rivers. b) Adult female's stranding events of I. g. humboldtiana in the Agua Limón spout (Arauca) in the Colombian Orinoquia.

droughts and intense floods. As already mentioned, river dolphins are highly dependent on the stability of the river pulses, and their effect in the maintenance of the different aquatic habitats they use to complete their biological cycle.

\section{Acknowledgements}

This study is part of the project: "Formulación del Plan de Conservación para el delfín de río o delfín rosado (Inia geoffrensis)". We thank the support of Corporinquia, as well as all the people that help us within the field work; we thank Colciencias (National Doctorate Scholarship 785); this research is part of the Strategic Plan of the South American River Dolphins Initiative (SARDI), supported by WWF in Brazil, Colombia, Perú, Ecuador and Bolivia. Special gratitude to M. Oliveira, S. Usma, D. Amorocho, D. Willems, K. Berg, L. Sainz, J. Rivas, J. L. Mena, J. Surkin, and M. Wulms from the WWF network.

\section{Literature cited}

Alcamo, J., P. Döll, T. Henrichs, F. Kaspar, B. Lehner, T. Rösch, AND S. Siebert. 2003. Global estimates of water withdrawals and availability under current and future business-as-usual conditions. Hydrobiology Science Journal 48:339-348.

Alcamo, J., D. Van Vuuren, and W. Cramer. 2005. Changes in ecosystem services and their drivers across the scenarios. 
Anonymous Scenarios. Millennium Ecosystem Assessment. Washington, U.S.A.

Aliaga-Rossel, E. 2002. Distribution and abundance of the pink river dolphin, bufeo (Inia geoffrensis) in the Tijamuchi River, Beni-Bolivia. Aquatic Mammals 28:312-323.

Aliaga-Rossel, E., T. L. Mcguire, and H. Hamilton. 2006. Distribution and encounter rates of the river dolphin (Inia geoffrensis boliviensis) in the central Bolivian Amazon. Journal of Cetacean Research and Management 8:87-92.

Alkemade, R., M. Van Oorschot, L. Miles, C. Nellemann, M. Bakkenes, and B. Ten Brink. 2009. GlOBIO3: a framework to investigate options for reducing global terrestrial biodiversity loss. Ecosystems 12:374-390.

Andrade, G., L. G. Castro, A. Durán, M. Rodríguez, G. Rudas, E. URIBE, AND E. WILLS. 2009. La mejor Orinoquia que podemos construir. Elementos para la sostenibilidad ambiental del desarrollo. Corporinoquia - Universidad de los Andes Foro Nacional Ambiental - Friedrich Ebert Stiftung (ESCOL), Bogotá. D.C., Colombia.

Avila, I. C., K. Kaschner, and C. F. Dormann. 2018. Current global risks to marine mammals: taking stock of the threats. Biological Conservation 221:44-58.

Banguera-Hinestroza, E., H. Cardenas, M. Ruiz-Garcia, M. Marmontel, E. Gaitan, R. Vazquez, and F. García-Vallejo. 2002. Molecular identification of evolutionarily significant units in the Amazon river dolphin Inia sp. (Cetacea: Iniidae). Journal of Heredity 93:312-322.

BAUM, J. K., AND B. Worm. 2009. Cascading top-down effects of changing oceanic predator abundances. Journal of Animal Ecology 78:699-714.

Bennett, H. H., M. Mullen, P. Stewart, J. Sawyer, and E. Cliff Webber. 2004. Development of an invertebrate community index for an Alabama coastal plain watershed. Journal of the American Water Resources Association 40:43-51.

Boede, E. O., E. Mujica-Jorquera, F. Boede, and C. Varela. 2018. Reproductive management of the Orinoco river dolphin Inia geoffrensis humboldtiana in Venezuela. International Zoo Yearbook 52:245-257.

Buckland, S. T., D. R. Anderson, K. P. Burnham, and J. L. LaAke. 2001. Introduction to Distance Sampling: Estimating abundance of biological populations. Oxford University Press. Oxford, UK.

Caballero, S., F. Trujillo, A. Del Risco, Herrera, O. and A. Ferrer. 2017. Genetic identity of Sotalia dolphins from the Orinoco River. Marine Mammal Science 33:1214-1223.

Caballero, S., F. Trujillo, J. A. Vianna, H. Barrios-Garrido, M. G. Montiel, S. Beltran-Pedreros, M. Marmontel, M. C. O. Santos, M. R. Rossi-Santos, F. R. Santos, and C. S. Baker. 2007. Taxonomic status of the genus Sotalia: species level ranking for "tucuxi" (Sotalia fluviatilis) and "costero" (Sotalia guianensis) dolphins. Marine Mammal Science 23:358-386.

Carvajal-Castro, J. D., T. Velásquez-Roa, H. Mantilla-Meluk, F. Trujillo, and F. Mosquera-Guerra. 2015. Modelación de nicho y aspectos biogeográficos del género Sotalia (Cetartiodactyla: Delphinidae) en los ríos Amazonas y Orinoco, Colombia. Momentos de Ciencia 12:121-125.

Chapin, F., E. Zavaleta, V. Eviner, R. Naylor, P. Vitousek, H. Reynolds, D. Hooper, S. Lavorel, O. Sala, S. Hobbie, M. Mack,
And S. Díaz. 2000. Consequences of changing biodiversity. Nature 405:234-242.

Ciat, Cormacarena, Corporinoquia, Ecopetrol. 2018. Plan Regional Integral de Cambio Climático para la Orinoquía - Vichada, Resumen Ejecutivo. Publicación No. 461. Yopal. Casanare, Colombia.

Consejo Nacional de Piatolitica Económica y Social. 2014. Diseño e implementación de los beneficios económicos peródicos (BEPS). Bogotá, Colombia. https://colaboracion. dnp.gov.co/CDT/Conpes/Social/156.pdf. Accessed 7 June 2019.

Convetion On International Trade in Endangered Species. 2019. Convention on International Trade in Endangered Species of Wild Fauna and Flora. www.cites.org. Accessed 22 May 2019.

Departamento Administrativo Nacional de Estadística. 2018. Resultados Censo Nacional de población y Vivienda. www. dane.gov.co/index.php/estadisticas-por-tema/demografiay-poblacion/censo-nacional-de-poblacion-y-vivenda-2018. Accessed 13 February 2019.

Da Silva, V. M. F. 2002. Amazon River dolphin Inia geoffrensis. Pp. 18-20 in Encyclopedia of Marine Mammals (Perrin, W. F., B. Wursig, and J. G. M. Thewissen, eds.). Academic Press. San Diego, U.S.A.

Da Silva, V. M. F. 2009. Amazon river dolphin, Inia geoffrensis. Pp. 26-28 in Encyclopedia of marine mammals (Perrin, W. F., ed.). Academic Press. Amsterdam, Nederland.

Da Silva, V. M. F., A. R. Martin, and N. A. S. Do Carmo. 2011. Amazonian fisheries pose threat to elusive dolphin species. Species (Gland) 53:10-11.

Da Silva, V., F. Trujillo, A. Martin, A. N. Zerbini, E. Crespo, E. Aliaga-Rossel, and R. Reeves. 2018. Inia geoffrensis. The IUCN Red List of Threatened Species 2018: e.T10831 A50358152.

Davidson, A. D., A. G. Boyer, H. Kim, S. Pompa-Mansilla, M. J. Hamilton, D. P. Costa, G. Ceballos, and J. Brown. 2012. Drivers and hotspots of extinction risk in marine mammals. Proceedings of the National Academy of Sciences of the United States of America PNAS 109:3395-3400.

Davidson, A. D., M. J. Hamilton, A. G. Boyer, J. H. Brown, ANd G. Ceballos. 2009. Multiple ecological pathways to extinction in mammals. Proceedings of the National Academy of Sciences of the United States of America PNAS106 26:10702-10705.

Dawson, T. 2011. Beyond Predictions Biodiversity Conservation in a Changing Climate. Science 53:53-58.

Departamento Nacional de Planeación. 2014. CONPES 3797 Política para el desarrollo integral de la Orinoquia: altillanura - fase I. Consejo Nacional de Política Económica y Social. Bogotá, Colombia.

Diazgranados M. C., And F. Trujlllo. 2004. Fauna Acuática en la Orinoquia colombiana. Pontificia Universidad Javeriana, Instituto de Estudios Ambientales para el Desarrollo - IAvH GTZ. Bogotá, Colombia.

Environmental Systems Research Institute. 2014. ArcGIS Desktop: Release 10.2.x. Environmental Systems Research Institute. Redlands, California, U.S.A.

Environmental Systems Research Institute. 2019. ArcGis Desktop: Release 10.2.x. Environmental Systems Research Institute. Redlands, U.S.A. www.pro.arcgis.com/es/pro-app/ tool-reference/data-management/resample.htm. Accessed 
15 March 2019.

Falkenmark, M. 1997. Meeting water requirements of an expanding world population. Philosophical Transactions of the Royal Society. Biology Sciences 352:929-936.

Foley, J. A., R. Defries, G. P. Asner, C. Barford, G. Bonan, S. R. Carpenter, F. S. Chapin, M. T. Coe, G. C. Daily, and H. K. Gibbs. 2005. Global consequences of land use. Science 309:570. https://doi.org/10.1126/science. 1111772

Global International Water Assessment. 2002. Methodology. University of Kalmar, UNEP. Kalmar, Sweden.

Gomez-Salazar, C., F. Trujlllo, and H. Whitehead. 2011. Population size estimates of pink river dolphins (Inia geoffrensis) using mark-recapture methods on photoidentification. Latin American Journal of Aquatic Mammals 6:40-47.

Gomez-Salazar, C., F. Trujlllo, M. Portocarrero-Aya, and H. Whitehead. 2012a. Population, density estimates, and conservation of river dolphins (Inia and Sotalia) in the Amazon and Orinoco river basins. Marine Mammal Science 28:24-42.

Gomez-Salazar C., M. Coll, and H. Whitehead. 2012b. River dolphins as indicators of ecosystem degradation in large tropical rivers. Ecological Indicators 23:19-26.

Graham, C., and Humans, R. J. 2006. A comparison of methods for mapping species ranges and species richness. Global Ecology and Biogeography 578-587.

Gravena, W., P. F. Izeni, M. N. F. Da Silva, V. M. F. Da Silva, and T. HRBEK. 2014. Looking to past and the future: were the Madeira River rapids a geographical barrier to the boto (Cetacea: Iniidae)? Conservation Genetics 15:619-629.

Herrera, O., A. Ferrer, E. Boede, F. Trujillo, F. MosqueraGuerra, S. Usma, E. Mujica, S. Сobarrubia, and K. Diniz. 2017. Tonina del Orinoco Inia geoffrensis (Blainville, 1817). Pp. 12-17 in Plan de acción para la conservación de los mamíferos acuáticos de Venezuela: delfines de agua dulce, nutrias y manatíes 2017-2027 (Ferrer, A., O. Herrera., F. Trujillo., F. Mosquera-Guerra., G. De La Cruz Melo., D. Lew., S. Boher., A. E. Seijas., O. Hernández, and S. Usma, eds.). Unión Gráfica. Caracas, Venezuela.

Hijmans, R. J., S. E. Cameron, J. L. Parra, P. G. Jones, and A. Jarvis. 2005. Very high resolution interpolated climate surfaces for global land areas. International Journal of Climatology 25:1965-1978.

Hoekstra, A. Y., A. K. Chapagain, M. M. Aldaya, and M. M. Mekonnen. 2011. The Water Footprint Assessment Manual: Setting the Global Standard. Earthscan, UK.

Hrbek, T., V. M. F Da Silva, N. Dutra, W. Gravena, A. R. Martin, and I. P. Farias. 2014. A new species of river dolphin from Brazil or: how little do we know our biodiversity. PlosOne 9:1-12.

International Union for Conservation Nature, and Natural Resources. 2013. Why is biodiversity in crisis? In IUCN 2013. The IUCN what biodiversity about biodiversity crisis. www.iucn.org/ what/biodiversity/about/biodiversity crisis. Accessed 22 May 2019.

International Union for Conservation Nature, and Natural ResourCes. 2019. Inia geoffrensis. In IUCN 2019. The IUCN Red List of Threatened Species. Version 2019.1. www.iucnredlist. org/species/10831/3220342. Accessed 7 June 2019.

International Whaling Commission. 2000. Report of the Scientific Sub-Committee on Small Cetaceans. International Whaling Commission Scientific Committee. Journal of Cetacean Research and Management 3:263-291.

KaRR, J.R., AND E.W. Chu. 1999. Restoring Life in Running Waters: Better Biological Monitoring. Island Press. Washington, U.S.A.

Martin, A. R., AND V. M. F. DA Silva. 2018. Reproductive parameters of the Amazon river dolphin or boto, Inia geoffrensis (Cetacea: Iniidae); an evolutionary outlier bucks no trends. Biological Journal of the Linnean Society 20:1-11.

Martin, A. R., V. M. F, Da Silva, And D. L. Salmon. 2004. Riverine habitat preferences of botos (Inia geoffrensis) and tucuxis (Sotalia fluviatilis) in the central Amazon. Marine Mammal Science 20:189-200.

Martin A. R., ANd V. M. F. DA Silva. 2006. Sexual dimorphism and body scarring in the boto (Amazon River dolphin) Inia geoffrensis. Marine Mammal Science 22:25-33.

Milà Canals, L., J. Chenoweth, A. Chapagain, S. Orr, A. Antón, ANd R. CLIft. 2009. Assessing freshwater use impacts in LCA: Part I - inventory modelling and characterization factors for the main impact pathways. International Journal Life Cycle Assessment 14:28-42.

Minambiente. 2017. www.minambiente.gov.co/images/ normativa/app/resoluciones/75-res\%201912\%20de $\% 20$ 2017.pdf. Accessed 8 August 2019.

Mintzer, V. J., A. R. Martin, V. M. F. Da Silva, A. B. Barbour, K. Lorenzen, AND T. K. Frazer. 2013. Effect of illegal harvest on apparent survival of Amazon River dolphins (Inia geoffrensis). Biological Conservation 158:280-286.

Mosquera-Guerra, F., C. Parra, F. Trujillo, A. M. JiménezOrtega, and H. Mantilla-Meluk. 2015. Valoración estacional de las amenazas contra la conservación de Inia geoffrensis humboldltiana (Cetartiodactyla Iniidae) en la cuenca del Río Meta, Colombia. Therya 6:371-388.

Mosquera-Guerra F., F. Trujillo, D. Caicedo-Herrera, and S. Martínez-Callejas. 2015a. Indicios de biomagnificación de Mercurio total $(\mathrm{Hg})$ en las especies del género Inia (Cetartiodactyla: Iniidae) en los ríos Amazonas y Orinoco (Colombia). Momentos de Ciencia 12:145-149.

Mosquera-Guerra F., F. Trujillo, M. C. Díaz-Granados, and H. Mantilla-Meluk. 2015b. Conservación de delfines de río (Inia geoffrensis y Sotalia fluviatilis) en los ecosistemas acuáticos de la Amazonia y Orinoquia en Colombia. Momentos de Ciencia 12:77-86.

Mosquera-Guerra, F., F. Trujillo, D. Caicedo-Herrera, J. ZoqueCancelado, and H. Mantilla-Meluk. 2015c. Impactos de las pesquerías de Calophysus macropterus un riesgo para la salud pública y la conservación de los delfines de río en Colombia. Momentos de Ciencia 12:88-99.

Mosquera-Guerra, F., F. Trujillo, B. Barrera, and E. Sánchez. 2016. Plan de manejo de los delfines de río en el área de jurisdicción de Cormacarena. Corporación para el desarrollo sostenible del área de manejo especial La Macarena (Cormacarena) y la Fundación Omacha. Bogotá, Colombia.

Mosquera-Guerra, F., F. Trujillo, C. Parra, J. D. Carvajal-Castro, and H. Mantilla-Meluk. 2018. Aspectos poblacionales y biogeográficos de la tonina o delfín de río, Inia geoffrensis humboldtiana Pilleri and Gihr, 1978 (Cetartiodactyla, Iniidae) 
en los ríos Guayabero y Losada, sierra de La Macarena, Meta, Colombia. Pp. 289-304 in V Biodiversidad de la sierra de La Macarena, Meta, Colombia. Parte I. Ríos Guayabero medio, bajo Losada y bajo Duda (Lasso, C. A., M. A. MoralesBetancourt, and I. D. Escobar-Martínez, eds.). Serie Editorial Fauna Silvestre Neotropical. Instituto de Investigaciones de Recursos Biológicos Alexander von Humboldt. Bogotá, Colombia.

Mosquera-Guerra, F., F. Trujillo, P. Danni, M. Oliveira-da-Costa, M. Marmontel, D. Armenteras-Pascual, S. Usma, D. Willems, J. D. Carvajal-Castro, H. Mantilla-Meluk, N. Franco, D. Amorocho, R. Maldonado, K. Berg, L. Sainz, P. A. Van Damme, and E. Cambell. 2018a. Analysis of distribution of river dolphins (Inia and Sotalia) in protected and transformed areas in the Amazon and Orinoco basins. Scientific committee, Meetings, SC67B, Slovenia.

Mosquera-Guerra, F., F. Trujillo, M. Oliveira-da-Costa, M. Marmontel, D. Armenteras- Pascual, S. Usma, D. Willems, J. D. Carvajal-Castro, H. Mantilla-Meluk, N. Franco, D. Amorocho, R. Maldonado, K. Berg, L. Sainz, and P. A Van Damme. 2018b. Movements and habitat use of river dolphins (Cetartiodactyla: Iniidae) in the Amazon and Orinoco river basins, determined from satellite tagging. Scientific Committee, Meetings, SC67B Slovenia.

Mosquera-Guerra, F., F. Trujillo, D. Parks, M. Oliveira-da-Costa, S. Usma, D. Willems, R. Maldonado, D. Amorocho, K. Berg, D. Armenteras-Pascual, P. A. Van Damme, L. Sainz, N. Franco, H. Mantilla-Meluk, J. D. Carvajal-Castro, E. Cambell, L. Cordova, A. Echeverria, S. Caballero, and M. Marmontel. 2018c. Presence of mercury in river dolphins (Inia and Sotalia) in the Amazon and Orinoco basins: evidence of a growing threat for these species. Scientific Committee, Meetings, SC67B, Slovenia.

Moyle, P. M., ANd P. J. Randall. 1998. Evaluating the biotic integrity of watersheds in the Sierra Nevada, California. Conservation Biology 12:1318-1326.

Pavanato, H., G. Melo-Santos, D. Lima, M. Portocarrero-Aya, M. Paschoalini, F. Mosquera, F. Trujlllo, R. Meneses, M. Marmontel, AND C. Maretti. 2016. Risk of dam construction for South American River Dolphins: a case of study of the Tapajós River. Endangered Species Research 31:47-60.

Phillips, S. J., R. P. Anderson, And R. E. Schapire. 2006. Maximum entropy modeling of species geographic distributions. Ecological Modelling 190:231-259.

Phillips, S. J., M. Dudík, J. Elith, C.H. Graham, A. Lehmann, J. Leathwick, and S. Ferrier. 2009. Sample selection bias and presence-only distribution models: implications for background and pseudo-absence data. Ecological Applications 1:181-97.

R Core Team. 2011. R: A language and environment for statistical computing. R Foundation for Statistical Computing. Vienna, Austria. http://www.R-project.org/.

R Core Team. 2013. R: A language and environment for statistical computing. R Foundation for Statistical Computing. Vienna, Austria. http://www.R-project.org/.

Revenga, C., J. Brunner, N. Henninger, K. Kassem, and R. Payne. 2000. Pilot Analysis of Global Ecosystems: Freshwater Systems. Washington, U.S.A.

Reeves, R. R., and S. Leatherwood. 1994. Dolphins, porpoises and whales: 1994-98 action plan for the conservation of cetaceans. IUCN, Gland, Switzerland.

Reeves, R. R. 2000. Report of the workshop to develop a conservation action plan for the Yangtze River finless porpoise, Ocean Park, Hong Kong, 16-18 September 1997. Pp. 97-80 in Biology and conservation of freshwater cetaceans in Asia (Reeves, R. R., B. D. Smith., and T. Kasuya, eds). Occasional Paper of the IUCN Species Survival Commission, Gland, Switzerland.

Reeves, R. R., B. Smith, E. A. Crespo, and G. Notarbartolo Di Sciara (Eds.). 2003. Dolphins, whales and porpoises. 20022010 Conservation Action Plan for the world's Cetaceans. IUCN/SSC Cetacean Specialist Group. Gland, Switzerland and Cambridge, UK.

Romero, M., G. Galindo, J. Otero, and D. Armenteras. 2004. Ecosistemas de la cuenca del Orinoco colombiano. Instituto de Investigación de Recursos Biológicos Alexander von Humboldt. Bogotá, Colombia.

Ross, P. S., S. Z Dungan, S. K. Hung, T. A Jefferson, C. Macfarquhar, W. F. Perrin, K. N. Rieht, E. Slooten, J. Tsal, J. Y. Wang, B. N. White, B. Wursig, S. C. Yang, and R. R. Reeves. 2010. Averting the baiji syndrome: conserving habitat for critically endangered dolphins in Eastern Taiwan Strait. Aquatic Conservation: Marine and Freshwater Ecosystems 20:685-694.

Ruiz-Garcia, M., S. Caballero, M. Martinez- Aguero, And J. Shostell. 2008. Molecular differentiation among Inia geoffrensis and Inia boliviensis (Iniidae, Cetacea) by means of nuclear intron sequences. Pp. 177-223 in Population genetics research progress (Koven, V. P, ed.). Nova Science Publishers, Inc. Hauppauge, U.S.A.

Ruiz-Garcia, M. 2010. Changes in the demographic trends of Pink River Dolphins (Inia) at the microgeographical level in Peruvian and Bolivian rivers and within the Upper Amazon: Microsatellites and mtDNA analyses and insights into Inia's origin. Pp. 225-258 in Biology, evolution, and conservation of river dolphins within South America and Asia: Unknown dolphins in danger (Ruiz-García M. and J. Shostell, eds.). Nova Science Publishers, Inc. Hauppauge, U.S.A.

Sandin, S. A., J. E. Smith, E. E. DeMartini, E. A. Dinsdale, S. D. Donner, A. M. Friedlander, T. Konotchick, M. Malay, J. E. Maragos, And D. Obura. 2008. Baselines and degradation of coral reefs in the northern Line Islands. PLoS ONE 3:1-11.

Sittig, L., U. Römer, C. Gilleman, and N. G. Gongora-Torres. 2018. Population numbers of Amazon river dolphins Inia geoffrensis and Sotalia fluviatilis (Mammalia: Cetaceae: Delphinidae) in the lower Río Tigre region, Loreto, Perú. Vertebrate Zoology 68:213-224.

Smith, B., G. Braulik, S. Strindberg, B. Ahmed, and R. Mansur. 2006. Abundance of Irrawaddy dolphins (Orcaella brevirostris) and Ganges river dolphins (Platanista gangetica gangetica) estimated using concurrent counts made by independent teams in waterways of the Sundarbans mangrove forest in Bangladesh. Marine Mammal Science 22:527-547.

Smith, B., ANd G. Braulik. 2008. Platanista gangetica. 2009. In: IUCN Red List of Threatened Species. Version 2019.1. www. iucnredlist.org. Accessed 8 August 2019.

Peterson, A. T., M. Papeş, And M. Eaton. 2007. Transferability and model evaluation in ecological niche modeling: a comparison of GARP and Maxent. Ecography 30:550-560.

Trusilzo, F. 2000. Habitat use and social behavior of the 
freshwater dolphin Inia geoffrensis (De Blainville, 1817) in the Amazon and Orinoco basins. Ph.D. thesis, University of Aberdeen. Aberdeen, Scotland.

Trujlllo, F., And M. C. Diazgranados. 2004. Variación estacional en el uso del hábitat del delfín de río, Inia geoffrensis humboldtiana, en la Orinoquía Colombiana. Pp. 138 in Fauna Acuática de la Orinoquía Colombiana (Diazgranados M. C., and F. Trujillo, eds.). Instituto de Estudios Ambientales para el Desarrollo. Pontificia Universidad Javeriana. Bogotá, Colombia.

Trujillo, F., M. C. Diazgranados, A. Galindo, and L. fuentes. 2006. Delfín rosado Inia geoffrensis. Pp. 285 in: Libro rojo de los mamíferos de Colombia (Rodríguez-M. J. V., M. Alberico., F. Trujillo, and J. Jorgenson, eds.). Serie Libros Rojos de Especies Amenazadas de Colombia. Conservación internacional Colombia, Ministerio de Ambiente, Vivienda y Desarrollo Territorial. Bogotá, Colombia.

Trujlllo, F., E. Crespo, P. van Damme, and J. S. Usma. 2010. The Action Plan for South American River Dolphins 2010 - 2020. WWF, Fundación Omacha, WCS, WDCS, Solamac. Bogotá, Colombia.

Trujillo, F., E. Crespo, P. Van Damme, S. Usma, D. MoralesBetancourt, A. Wood, And M. Portocarrero. 2010a. Summary of threats for river dolphins in South America: past, present and future. Pp. 145-158 in: The Action Plan for South American River Dolphins 2010-2020 (Trujillo, F., E. Crespo., P. Van Damme, and J. S. Usma, eds.). WWF, Fundación Omacha, WCS, WDCS, Solamac. Bogotá, Colombia.

Trujlllo, F., C. Gomez-Salazar, M. Portocarrero, E. Aliaga-Rossel, V. Utreras, S. Usma, and G. Tavera. 2011. Estimaciones de abundancia de delfines de río: una herramienta para diseñar estrategias de conservación. Pp. 57-70 in Plan de Acción para la conservación de los delfines de río en Sudamérica: Resumen Ejecutivo y Avances 2010-2020 (Trujillo, F., E. Crespo., P. Van Damme, and J. S. Usma, eds.). WWF, Fundación Omacha, WCS, WFN, Solamac. Bogotá, Colombia.

Trujlllo, F., C. Gomez., S. Martínez., O. Herrera, and F. MosqueraGuerRA. 2016. Estimaciones de densidad, y conservación del delfín de río (Inia geoffrensis) en el río Meta. Pp. 2 - 28 in Biodiversidad de la cuenca baja y media del río Meta. (Trujillo, F., R. Antelo, and J. S. Usma, eds.). Fundación Omacha, Fundación Palmarito, WWF. Bogotá, Colombia.

Trujillo, F., F. Mosquera, and N. Franco. 2019. Delfines de Río: Especies indicadores del estado de salud en los ecosistemas acuáticos de la Amazonia y Orinoquia. Revista Colombiana de Ciencias Exactas, Físicas y Naturales 43:199-211.

Turvey, S. T., R. L. Pitman, B. L. Taylor, J. Barlow, T. Akamatsu, L. A. Barrett, X. Zhao, R. R. Reeves, B. S. Stewart, K. Wang, Z. Wel, X. Zhang, L. T. Pusser, M. Richlen, J. R. Brandon, and D. Wang. 2007. First human-caused extinction of a cetacean species? Biology Letters 3:537-40.

Vörösmarty, C. J., P., Green, J., Salisbury, and R. B. Lammers. 2000. Global water resources: vulnerability from climate change and population growth. Science 289:284-288.

Vörösmarty, C. J., P. B. Mcintyre, M. O. Gessner, D. Dudgeon, A. Prusevich, P. Green, S. Glidden, S. E. Bunn, C. A. Sullivan, And C. R. Liermann. 2010. Global threats to human water security and river biodiversity. Nature 467:555-561.

Wilcove, D., D. Rothstein, J. Dubow, A. Phillips, and E. Losos. 1998. Quantifying threats to imperiled species in the United
States. BioScience 48:607-615.

Williams, R., J. Moore, C. Gomez-Salazar, F. Trujillo, and L. BURT. 2016. Searching for trends in river dolphin abundance: Designing surveys for looming threats, and evidence for opposing trends of two species in the Colombian Amazon. Biological Conservation 195:136-145.

Associated editor: Juan Pablo Gallo

Submitted: June 12, 2019; Reviewed: August 12, 2019;

Accepted:September 18, 2019; Published on line:December 2, 2019 
22 THERYA Vol. 11 (1): 9-21 